\title{
Effects of low-level laser therapy and epidermal growth factor on the activities of gingival fibroblasts obtained from young or elderly individuals
}

\author{
Taisa Nogueira Pansani ${ }^{1}$. Fernanda Gonçalves Basso ${ }^{2}$ - Ana Paula Silveira Turrioni ${ }^{3}$. \\ Diana Gabriela Soares ${ }^{1} \cdot$ Josimeri Hebling $^{2}$ - Carlos Alberto de Souza Costa ${ }^{4}$
}

Received: 9 March 2016 / Accepted: 19 September 2016 / Published online: 27 September 2016

(C) Springer-Verlag London 2016

\begin{abstract}
This study evaluated the effects of low-level laser therapy (LLLT) and epidermal growth factor (EGF) on fibroblasts obtained from young and elderly individuals. Gingival fibroblasts from young $(\mathrm{Y})$ and elderly $(\mathrm{E})$ individuals were seeded in wells of 24-well plates with Dulbecco's modified Eagle's medium (DMEM) containing $10 \%$ of fetal bovine serum (FBS). After $24 \mathrm{~h}$, the cells were irradiated (LASERTable-InGaAsP-780 $\pm 3 \mathrm{~nm}, 25 \mathrm{~mW}, 3 \mathrm{~J} / \mathrm{cm}^{2}$ ) or exposed to EGF $(100 \mu \mathrm{M})$. After $72 \mathrm{~h}$, cells were evaluated for viability, migration, collagen and vascular endothelial growth factor (VEGF) synthesis, and gene expression of growth factors. Data were analyzed by Kruskal-Wallis and Mann-Whitney tests $(\alpha=5 \%)$. Y and E fibroblasts irradiated with laser or exposed to EGF showed increased viability and collagen synthesis. Enhanced cell migration was observed for Y fibroblasts after both treatments, whereas only the LLLT stimulated migration of E cells. VEGF synthesis was higher for $\mathrm{Y}$ and $\mathrm{E}$ cells exposed to EGF, while this synthesis was reduced when $\mathrm{E}$ fibroblasts were irradiated. Increased gene expression of VEGF was observed only for $\mathrm{Y}$ and $\mathrm{E}$
\end{abstract}

Carlos Alberto de Souza Costa

casouzac@foar.unesp.br

1 Department of Dental Materials and Prosthodontics, Araraquara School of Dentistry, University Estadual Paulista (UNESP), Araraquara, Brazil

2 Department of Orthodontics and Pediatric Dentistry, Araraquara School of Dentistry, University Estadual Paulista (UNESP), Araraquara, Brazil

3 Department of Pediatric Dentistry, School of Dentistry, University Federal Uberlândia (UFU), Uberlândia, Brazil

4 Department of Physiology and Pathology, Araraquara School of Dentistry, University Estadual Paulista (UNESP), Humaita, 1680. Centro, 14801903 Araraquara, SP, Brazil fibroblasts treated with LLLT. Regardless of a patient's age, the LLLT and EGF applications can biostimulate gingival fibroblast functions involved in tissue repair.

Keywords Cell biology · Fibroblast(s) · Growth factors · Laser(s) · Wound healing

\section{Introduction}

Aging is a result of the complex interactions of physical, biological, and biochemical processes that take place in all organisms [1]. Over the time, cells gradually lose their replicative potential and ability to respond to growth factors, which can reduce wound repair capacity [2]. Several studies have shown changes in migration capability, cell proliferation, and matrix protein synthesis by aged cells $[2,3]$. In addition to these functional losses, senescent cells also exhibit morphological and structural changes that can be related to decreased motility [3-5].

The wound healing process depends on several events involving cell proliferation and migration, aimed at the repopulation of the damaged area [6], and these events occur in response to the coordinated local release of growth factors and cytokines [7].

Stephens et al. [8] reported that gingival fibroblasts show increased repair capability when compared with skin fibroblasts. Faster wound healing in oral mucosa may be related to the salivary fluid and site-specific microflora $[9,10]$. However, few studies have evaluated the possible influence of age on the repair capacity of the oral mucosa, as shown for the skin.

It has been reported that physiological levels of epidermal growth factor (EGF) in saliva stimulate proliferation and migration of cells from the oral epithelium [11]. Moreover, 
specific growth factors can accelerate cell proliferation and wound healing [12-17]. Therefore, the use of EGF as a treatment for the acceleration of tissue repair of dermal and oral mucosal wounds has been expanding $[13,15,18]$.

In addition to growth factors, low-level laser therapy (LLLT) can also promote tissue repair, by increasing cell proliferation and expression of growth factors and also by modulating the synthesis of inflammatory cytokines by several cell types, including gingival fibroblasts [19-25].

Specifically, laser interaction with tissue depends on the optical properties of this type of light, such as wavelength, power output, exposure time, and energy density, in addition to the characteristics of the target tissue, such as the presence and types of chromophores [26]. Other than these factors, there are no data regarding the effects of this therapy on gingival fibroblasts obtained from young and elderly individuals.

Therefore, this study aimed to evaluate the effect of the application of epidermal growth factor (EGF) or low-level laser irradiation on the viability, cell migration capacity, collagen synthesis, and expression of growth factors of gingival fibroblasts obtained from young and elderly individuals.

\section{Materials and methods}

Gingival biopsies $\left(1 \mathrm{~mm}^{2}\right)$ from six healthy individuals [three young (Y) (from 18 to 25 years old) and three elderly (E) (over 65 years old)] were obtained during tooth extraction, implant placement, or ridge regularization with no tissue inflammation. All procedures were performed in accordance with policies of the Research Ethics Committee of the Araraquara School of Dentistry/UNESP, after approval (CAEE no. 13514813.6.0000.5416) and with the consent of the patients after signing the instrument of consent.

\section{Cell culture and experimental groups}

For the isolation of gingival fibroblasts, gingival tissue fragments were placed in 6-well plates (Techno Plastic Products (TPP), Trasadingen, Switzerland) containing $3 \mathrm{~mL}$ of Dulbecco's modified Eagle's medium (DMEM) culture medium (Gibco, Grand Island, NY) supplemented with antibiotic/ antimycotic solution $(10,000$ units $/ \mathrm{mL}$ penicillin, $10,000 \mathrm{mg} /$ $\mathrm{mL}$ streptomycin, and $25 \mu \mathrm{g} / \mathrm{mL}$ Fungizone $\AA$, Gibco) and type I collagenase $(3 \mathrm{mg} / \mathrm{mL}$ ) (Worthington Biochemical Corp., Lakewood, NJ, USA) and were incubated at $37{ }^{\circ} \mathrm{C}$ for $24 \mathrm{~h}$.

After this period, cells and the remaining fragments were transferred to a new flask in DMEM containing antibiotic/ antimycotic solution and $10 \%$ fetal bovine serum (FBS, Gibco). The culture medium was replaced every $72 \mathrm{~h}$ until the appropriate cell number for the experiment was achieved.
Subculture was performed with $0.25 \%$ trypsin (Invitrogen, Carlsbad, CA, USA) at $80 \%$ confluence.

For experimental protocols, cells (three to seven passages, using the same passage for all patients) were seeded in 24-well plates at different densities, according to each protocol, in complete culture medium for $24 \mathrm{~h}$. After this period, no treatment (control group), LLLT, or EGF application was performed in $\mathrm{Y}$ and $\mathrm{E}$ individual's group. For each experiment, two samples of each primary cell line from three different individuals were used in duplicate, total $n=12$. All groups were evaluated at the 72-h periods after the treatments according to the methodologies described later.

\section{Irradiation (LLLT)}

The LASERTable device [23, 26-28], composed of 12 diodes of the indio, gallium, arsenide, and phosphate (InGaAsP) type, was used for in vitro LLLT $(780 \pm 3 \mathrm{~nm}, 25 \mathrm{~mW})$.

Three irradiations were performed at 24 -h intervals at $3.0 \mathrm{~J} /$ $\mathrm{cm}^{2}$ energy density, determined based on results of previous studies showing that these parameters, 4-min time exposure in a continuous wave, are capable of promoting proliferation, metabolism, and gene expression for different cell types [21, $22,28,29]$.

\section{Epidermal growth factor}

EGF growth factor (Sigma-Aldrich, St. Louis, MO, USA) was diluted in serum-free DMEM culture medium at $100 \mu \mathrm{M}$ concentration and was maintained in contact with the cells at $37^{\circ} \mathrm{C}$ for $72 \mathrm{~h}$. This concentration was selected based on a pilot study that evaluated different concentrations capable to stimulate cell proliferation.

\section{Cell viability evaluation (alamarBlue ${ }^{\circledR}$ assay)}

Cellular metabolic activity was detected by an alamarBlue $\AA$ assay (Invitrogen). This method is based on the reduction of a redox indicator, which exhibits a color change that can be detected by absorbance or fluorescence, proportional to the mitochondrial activity. alamarBlue ${ }^{\circledR}$ solution $(10 \%$ in serum-free DMEM) was added to the cells and incubated at $37^{\circ} \mathrm{C}$ for $4 \mathrm{~h}$. The fluorescence of the resulting solution was read by spectrophotometry (Synergy H1; Biotek, Winooski, VT, USA) at $570 \mathrm{~nm}$ (excitation) and $600 \mathrm{~nm}$ (emission). The evaluation of metabolic activity was performed at 24,48 , and $72 \mathrm{~h}$.

\section{Cell migration (wound healing)}

The effect of LLLT or EGF on the migration of gingival fibroblasts was determined by an in vitro wound healing protocol [30]. After $24 \mathrm{~h}$ of cell culture, an in vitro "wound" was 
created in the central area of each compartment containing the precultured cells, by means of the tip of a $5-\mathrm{mL}$ pipette. The presence of the wound was confirmed by inverted light microscopy (TS 100, Nikon, Tokyo, Japan).

Then, cells were irradiated, and EGF was added as described above. Cell migration was evaluated at 24, 48, and $72 \mathrm{~h}$ after these treatments.

Migration was determined after the fixation of cells with $0.5 \mathrm{~mL}$ of $70 \%$ ethanol for $1 \mathrm{~h}$. Cells were then washed with $1 \mathrm{~mL}$ of distilled water, then stained with $0.5 \mathrm{~mL}$ of $0.1 \%$ crystal violet (Sigma-Aldrich) for $15 \mathrm{~min}$ and washed again with $1 \mathrm{~mL}$ of distilled water. As previously described by Basso et al. [22], the areas of the wounds were analyzed by means of an optical microscope (Olympus BX51, Miami, FL, USA) equipped with a digital camera (Olympus c 5060) and subjected to analysis by ImageJ software (Wayne Rasband, National Institute of Mental Health, Bethesda, MD, USA).

\section{Collagen synthesis (Sirius Red assay)}

The concentration of total collagen produced by gingival fibroblasts was determined by the Sirius Red assay, which quantifies the soluble collagen present in the sample by selective binding to the types I-IV of collagen fibers to the Direct Red dye (Sigma-Aldrich) in saturated picric acid [31].

Cells were seeded $\left(8 \times 10^{4}\right.$ cells/well $)$ in $0.5 \mathrm{~mL}$ of culture medium in 24-well plates. Treatments were performed according to the experimental groups, and a $400 \mathrm{~mL}$ quantity of culture medium was collected and stored at $-20{ }^{\circ} \mathrm{C}$ until analysis. To this volume of culture medium, $400 \mu \mathrm{L}$ of Direct Red solution ( $0.5 \mathrm{M}$ in picric acid) were added and maintained in a shaker (Thermomixer Comfort; Eppendorf, Hamburg, Germany) for $60 \mathrm{~min}$ under stirring (400 rpm, room temperature). Thereafter, samples were centrifuged in a refrigerated microcentrifuge (Eppendorf 5415R) for $10 \mathrm{~min}$ at 12,000 relative centrifugal force ( $\mathrm{rcf}$ ), and the resulting supernatant was discarded. $\mathrm{HCl} 0.1 \mathrm{M}(300 \mathrm{~mL})$ was added, and samples were centrifuged again for the same time and at the same speed. The supernatant was again discarded, and $250 \mathrm{~mL}$ of $0.5 \mathrm{M} \mathrm{NaOH}$ was added to the samples for homogenization. Aliquots of $100 \mathrm{~mL}$ of the solution, in duplicate, were transferred to 96well plates, and the absorbance $(555 \mathrm{~nm})$ was analyzed by spectrophotometry (Synergy H1, Biotek).

\section{Vascular endothelial growth factor synthesis}

During the wound healing process, several growth factors are expressed, including vascular endothelial growth factor (VEGF), which induces local angiogenesis as well as the proliferation and migration of mucosa cells.

The VEGF synthesis was evaluated by the enzyme-linked immunosorbent assay (ELISA), based on antigen-antibody reaction, which was performed according to the manufacturer's recommendations (R\&D Systems, Minneapolis, MN, USA). The culture medium in contact with the cells during proposed treatments was collected and stored at $-20{ }^{\circ} \mathrm{C}$ until the test.

For the assay, the ELISA plate was treated with specific primary antibodies $(1.0 \mu \mathrm{g} / \mathrm{mL}$ VEGF) and incubated overnight at room temperature. The samples were washed in a $2.5 \%$ wash solution, followed by incubation with blocking solution ( $1 \%$ bovine serum albumin (BSA) in PBS) for $1 \mathrm{~h}$ at room temperature.

After samples were washed, $100 \mu \mathrm{L}$ of each sample was added, accompanied by standard curve samples with predetermined VEGF concentrations, and the plates were incubated for $2 \mathrm{~h}$ at room temperature, followed by further washing. Next, the secondary antibody was added (100 ng/ $\mathrm{mL}$ ) and incubated for an additional $2 \mathrm{~h}$. After the samples were washed, streptavidin (1:400 in 1\% BSA) was then added to the samples for $20 \mathrm{~min}$ in the absence of light. New washes were performed, and the substrate solution was added and maintained for $20 \mathrm{~min}$. Finally, stop solution was added to stop the reaction, and the optical density of the samples was measured by spectrophotometry (Synergy H1, Biotek) at a $450 \mathrm{~nm}$ wavelength. VEGF concentrations were determined according to the standard curve.

\section{Gene expression (RT-PCR)}

Total RNA isolation was performed with the RNAqueous kit (Applied Biosystems) by using a filtration system. Next, the RNA concentration of each sample was determined spectrophotometrically (Take System 3-Synergy H1). For each RNA sample obtained, complementary DNA (cDNA) was synthesized for the qPCR protocol. Implementation of this protocol involved the High-Capacity cDNA Reverse Transcriptions Kit (Applied Biosystems, Foster City, CA, USA). To a microfuge tube were added $10 \times$ RT buffer, $10 \times$ random primers $\mathrm{RT}, 25 \times \mathrm{dNTP}$ mix, reverse transcriptase, and $0.5 \mu \mathrm{g}$ of RNA from each sample. Next, the samples were subjected to an amplification cycle recommended by the manufacturer (Applied Biosystems): $25{ }^{\circ} \mathrm{C}(10 \mathrm{~min}), 37{ }^{\circ} \mathrm{C}$ (120 min), $85{ }^{\circ} \mathrm{C}(5 \mathrm{~s})$, and $4{ }^{\circ} \mathrm{C}(\infty)$ (Thermocycler, BioRad, Hercules, CA, USA).

After cDNA synthesis, gene expression of VEGF, EGF, and basic fibroblast growth factor (FGF-2) was determined by quantitative real-time polymerase chain reaction (PCR). The reactions were prepared with standardized reagents for real-time PCR TaqMan Universal PCR Master Mix (Applied Biosystems), by adding the sets of specific primers and probes for each gene. Fluorescence readings were carried out every amplification cycle, with StepOnePlus (Applied Biosystems) and subsequently analyzed by StepOne 2.1 software (Applied Biosystems). All reactions were normalized by the signal 
Table 1 Cell viability (\% of control) of gingival fibroblasts obtained from young and elderly individuals according to the therapy

\begin{tabular}{lll}
\hline Treatment & Young & Elderly \\
\hline Control & $100.00(80.21-118.01) \mathrm{B}^{\mathrm{a}}$ & $100.00(91.11-109.83) \mathrm{B}$ \\
EGF & $123.61(95.43-144.68) \mathrm{AB}$ & $110.32(99.30-118.98) \mathrm{AB}$ \\
LLLT & $160.71(125.93-189.85) \mathrm{A}$ & $115.31(105.83-122.66) \mathrm{A}$
\end{tabular}

Values indicate median ( 25 th-75th percentiles), $n=12$. Values with the same letter are not statistically significantly different from each other (Mann-Whitney, $p>0.05$ )

${ }^{a}$ Capital letters allow for comparisons in columns

reference ROX passive dye to correct fluctuations in reading due to changes in volume and evaporation over the reaction.

The result, expressed in CT value (for the number of PCR cycles required for the fluorescence signal to reach the threshold of detection), was transferred to worksheets and normalized according to the selected endogenous gene expression (BAct). Next, the mRNA levels of each gene were subjected to target-specific statistical analysis.

\section{Statistical analysis}

Since data were not normally distributed (Shapiro-Wilk test), results were statistically analyzed by the Kruskal-Wallis test complemented by the Mann-Whitney test, at a $5 \%$ level of significance. For all tests, the data for the respective control groups (no treatment) were considered as $100 \%$, and the results obtained for EGF and LLLT were normalized by percentage.

\section{Results}

\section{Cell viability (alamarBlue ${ }^{\circledR}$ assay)}

Results demonstrated that only the LLLT (three irradiations at $3.0 \mathrm{~J} / \mathrm{cm}^{2}$ ) for both $\mathrm{Y}$ and $\mathrm{E}$ fibroblasts promoted a significant increase in cell viability compared with the respective control group $(p<0.05)$ (Table 1).

\section{Cell migration (wound healing)}

Migration of $\mathrm{Y}$ and $\mathrm{E}$ fibroblasts is presented in Tables 2 and 3. Increased migration, demonstrated as diminished wound area, was observed for Y fibroblasts without treatment at the 72-h period $(p<0.05)$. When these cells were subjected to the proposed therapies (EGF or LLLT), increased cell migration was observed, regardless of the evaluation period, with no statistically significant difference between the applied treatments $(p>0.05)$.

For cells from $\mathrm{E}$ gingival tissue, no increased migration was observed in the absence of treatments $(p>0.05)$, while for the 24- and 48-h periods, there was increased cell migration when cells were subjected to LLLT $(p<0.05)$. At $72 \mathrm{~h}$, both therapies promoted higher cell migration when compared with the control group. However, the LLLT showed a greater stimulatory effect on gingival cells $(p<0.05)$.

\section{Collagen synthesis (Sirius Red)}

Increased collagen synthesis occurred when $\mathrm{Y}$ and $\mathrm{E}$ fibroblasts were subjected to both treatment modalities (EGF or LLLT) compared with the respective control (untreated) $(p<0.05)$ (Table 4).

\section{VEGF synthesis}

Comparison of the treatments applied to Y fibroblasts showed a higher VEGF synthesis when cells were exposed to EGF $(p<0.05)$, while the LLLT caused no significant stimulation of these cells in culture. For E fibroblasts, a significant increase in VEGF synthesis after treatment with EGF was observed, and this cell activity was reduced when the cells were subjected to LLLT as proposed in this study (Table 5).

\section{Growth factors' gene expression}

For $\mathrm{Y}$ and $\mathrm{E}$ fibroblasts, an increase in VEGF synthesis was observed when these cells were subjected to LLLT $(p<0.05)$ (Table 6). As for the other growth factors, there was no change
Table 2 Wound area (area in $\mathrm{mm}^{2} \times 10^{4}$ ) according to the therapy and evaluation period, for fibroblasts obtained from gingival tissue of young individuals

\begin{tabular}{llll}
\hline Treatment & \multicolumn{2}{l}{ Period (h) } & \\
\cline { 2 - 4 } & 24 & 48 & 72 \\
\hline Control & $20.05(17.71-32.82) \mathrm{Bb}^{\mathrm{a}}$ & $20.04(13.95-25.49) \mathrm{Bb}$ & $12.63(9.67-16.97) \mathrm{Ba}$ \\
EGF & $12.87(2.17-16.52) \mathrm{Aa}$ & $11.12(6.50-14.33) \mathrm{Aa}$ & $9.39(2.97-12.51) \mathrm{ABa}$ \\
LLLT & $7.96(6.94-12.70) \mathrm{Aa}$ & $6.11(3.66-11.38) \mathrm{Aa}$ & $4.47(2.55-8.56) \mathrm{Aa}$ \\
\hline
\end{tabular}

Values indicate median (25th-75th percentiles), $n=12$. Values with the same letter are not statistically significantly different from each other (Mann-Whitney, $p>0.05$ )

${ }^{a}$ Capital letters allow for comparison in columns, and lowercase letters allow for comparison in rows 
Table 3 Wound area (area in $\mathrm{mm}^{2} \times 10^{4}$ ) according to the therapy and evaluation period, for fibroblasts obtained from gingival tissue of elderly individuals

\begin{tabular}{llll}
\hline Treatment & \multicolumn{3}{l}{ Period $(\mathrm{h})$} \\
\cline { 2 - 4 } & 24 & 48 & 72 \\
\hline Control & $33.39(16.09-39.66) \mathrm{Ba}^{\mathrm{a}}$ & $21.58(13.29-28.39) \mathrm{Ba}$ & $21.78(9.42-25.45) \mathrm{Ca}$ \\
EGF & $25.96(8.64-39.08) \mathrm{ABa}$ & $11.45(6.14-18.66) \mathrm{ABa}$ & $13.35(9.93-16.33) \mathrm{Ba}$ \\
LLLT & $7.64(2.86-21.96) \mathrm{Aa}$ & $10.17(5.98-14.66) \mathrm{Aa}$ & $8.14(4.27-12.68) \mathrm{Aa}$ \\
\hline
\end{tabular}

Values indicate median (25th-75th percentiles), $n=12$. Values with the same letter are not statistically significantly different from each other (Mann-Whitney, $p>0.05$ )

${ }^{a}$ Capital letters allow for comparison in columns, and lowercase letters allow for comparison in rows in gene expression in experimental groups compared with the control $(p>0.05)$ (Table 6).

\section{Discussion}

Oral mucosa healing is related to intrinsic factors such as the presence of structural cells with regenerative potential, intense vascularization, and intense turnover rate of the connective tissue and epithelium [10]. It is also evident that saliva plays an important role during this event, providing a conductive environment for the rapid repair of damaged oral mucosa [10].

Among the different cell types, fibroblasts actively participate in the tissue repair process, proliferating, migrating, and filling the wound, in addition to contributing to the synthesis of growth factors and extracellular matrix molecules [10]. However, the structure and function of these cells can be altered by factors such as aging [32]. As previously reported, the aging process can cause inhibition of the synthesis of growth factors and basic structural proteins such as collagen and fibronectin [32], which is a glycoprotein directly linked to the cell adhesion capacity. The reduced expression of fibronectin by senescent cells can interfere with cell migration and proliferation, which are essential and interdependent processes for tissue repair [32].

Adults' gingival fibroblasts, in contrast to skin fibroblasts, have many properties similar to fetal fibroblasts, including morphology, growth, migration ability, and cytokine

Table 4 Collagen synthesis (\% of control) from gingival fibroblasts obtained from young and elderly individuals according to the therapy

\begin{tabular}{lll}
\hline Treatment & Young & Elderly \\
\hline Control & $97.61(82.81-116.35) \mathrm{B}^{\mathrm{a}}$ & $98.24(80.88-110.54) \mathrm{B}$ \\
EGF & $168.20(138.01-200.94) \mathrm{A}$ & $141.38(126.49-146.19) \mathrm{A}$ \\
LLLT & $137.24(100.79-171.90) \mathrm{A}$ & $121.95(110.37-130.74) \mathrm{A}$ \\
\hline
\end{tabular}

Values indicate median ( 25 th-75th percentiles), $n=12$. Values with the same letter are not statistically significantly different from each other (Mann-Whitney, $p>0.05$ )

${ }^{a}$ Capital letters allow for comparison in columns production [10]. It is possible that gingival fibroblasts are phenotypically unique in adult tissue, which may contribute to the accelerated healing of oral wounds with minimal scarring [10]. It was observed in the present study that $\mathrm{Y}$ and $\mathrm{E}$ fibroblasts subjected to laser therapy showed increased viability when compared with untreated cells (control). This result suggests that LLLT, at the parameters used in this study, can accelerate the proliferative capacity of these cells, as previously reported by Basso et al. [22].

Almost 20 years ago, it was demonstrated that, in injured tissues, the release of growth factors and plasma proteins causes changes in cell phenotypes and initiates their migration to the site of the wound [6]. During this event, cytoplasmic protrusions and controlled retraction of membership foci are produced by cells as a result of the expression of proteins involved in this process and can influence wound repair [33, 34]. Previous studies with gingival mucosa fibroblasts showed the high capacity of these cells to reorganize extracellular matrix molecules, and this fact is directly related to their high migration capability $[9,35]$. In this in vitro study, it was determined that, in general, the proposed therapies can enhance cell migration, as observed by the wound healing assay. For $\mathrm{Y}$ fibroblasts, both treatments resulted in a biostimulatory effect, while for the E cells, LLLT exerted a higher effect in all evaluation times performed (24, 48, and $72 \mathrm{~h})$.

In recent years, LLLT has been used to accelerate tissue repair, inducing increased local vascularization, collagen synthesis, and cell proliferation [36, 37]. It has been shown that

Table 5 VEGF synthesis (\% of control) of gingival fibroblasts obtained from young and elderly individuals according to the therapy

\begin{tabular}{lll}
\hline Treatment & Young & Elderly \\
\hline Control & $109.45(60.91-126.37) \mathrm{B}^{\mathrm{a}}$ & $100.91(94.03-113.75) \mathrm{B}$ \\
EGF & $234.17(148.50-323.88) \mathrm{A}$ & $122.03(110.71-130.05) \mathrm{A}$ \\
LLLT & $120.59(80.67-171.78) \mathrm{B}$ & $61.23(50.25-87.26) \mathrm{C}$ \\
\hline
\end{tabular}

Values indicate median (25th-75th percentiles), $n=12$. Values with the same letter are not statistically significantly different from each other (Mann-Whitney, $p>0.05$ )

${ }^{\text {a }}$ Capital letters allow for comparison in columns 
Table 6 Gene expression of EGF, VEGF, and FGF2 (\%) by human gingival fibroblasts obtained from young and elderly individuals, according to the different treatments

\begin{tabular}{|c|c|c|c|c|c|c|}
\hline $\begin{array}{l}\text { Treatment } \\
\text { Age }\end{array}$ & $\begin{array}{l}\text { EGF (\%) } \\
\text { Young }\end{array}$ & $\begin{array}{l}\text { EGF (\%) } \\
\text { Elderly }\end{array}$ & $\begin{array}{l}\text { VEGF (\%) } \\
\text { Young }\end{array}$ & $\begin{array}{l}\text { VEGF (\%) } \\
\text { Elderly }\end{array}$ & $\begin{array}{l}\text { FGF2 (\%) } \\
\text { Young }\end{array}$ & $\begin{array}{l}\text { FGF2 (\%) } \\
\text { Elderly }\end{array}$ \\
\hline Control & $100.01(33.69) \mathrm{A}^{\mathrm{a}}$ & $100.00(4.29) \mathrm{A}$ & 100.03 (31.72) B & 100.85 (13.70) B & $100.00(25.06) \mathrm{A}$ & $100.00(3.75) \mathrm{A}$ \\
\hline EGF & $122.35(45.15) \mathrm{A}$ & $211.28(126.25) \mathrm{A}$ & 74.55 (10.86) B & 139.53 (8.32) B & $98.52(15.12) \mathrm{A}$ & 116.74 (28.62) A \\
\hline LLLT & 133.08 (15.83) A & $180.35(63.57) \mathrm{A}$ & 165.09 (43.44) A & 98.05 (14.63) A & 86.79 (12.77) A & $82.03(15.15) \mathrm{A}$ \\
\hline
\end{tabular}

Values represent mean (standard deviation). Values represented by the same letter represent no statistically significant difference from each other ( $p>0.05$, Tukey)

${ }^{\text {a }}$ Capital letters allow for comparison in columns

the laser energy absorption by cells also promotes increased metabolism, stimulation of photoreceptors characterized by the mitochondrial respiratory chain, changes in cellular ATP levels, and release of growth factors $[38,39]$. A systematic literature review on the use of LLLT for the proliferation of different cell lines concluded that this therapy can stimulate cells in culture [40]. However, the authors emphasized that the response to laser irradiation in cells is dose-dependent, and this type of light can either stimulate or inhibit cell proliferation, according to the parameters used and the type of cell or tissue to be irradiated. As previously reported by other researchers $[21,22,25]$, this study demonstrated cell biostimulation when the primary culture of gingival fibroblasts was irradiated with a low-level laser. Analysis of these data also confirms the findings of Basso et al. [22], who applied the same irradiation parameters to fibroblasts.

Growth factors regulate several cellular events that promote tissue repair by binding to specific receptors expressed on the cell surface [14]. Fibroblasts are regulated by several growth factors such as EGF, FGF-2, transforming growth factor $\beta$ (TGF- $\beta$ ), platelet-derived growth factor (PDGF), and VEGF [14]. These factors can operate locally in an autocrine or paracrine manner, exerting their biological effects and consequently participating in the regeneration process [41]. However, the signaling mechanisms by which these growth factors regulate the function of aged fibroblasts remain poorly understood.

In this study, we observed an increase in collagen synthesis when $\mathrm{Y}$ and $\mathrm{E}$ fibroblasts were subjected to the different therapies (EGF or LLLT). Analysis of these data seems to indicate that either therapy may also be able to inhibit the production of collagenases and stimulate collagen production, especially in senescent cells. However, a previous research demonstrated that aged cells present reduced expression of membrane receptors, which could explain, at least in part, a decreased response of these cells even when exposed to high concentrations of growth factors and mitogens [42]. In addition, a reduction in the proliferation of senescent dermal fibroblasts was reported, due to the slight expression of membrane receptors sensitive to EGF [43]. Therefore, our results showed that
$\mathrm{Y}$ and $\mathrm{E}$ fibroblasts from oral mucosa can respond to both therapies (EGF or LLLT) inducing an increase in the activity of cellular functions to assist in efficient and faster tissue repair.

VEGF plays a fundamental role in tissue repair, since revascularization is a dynamic event necessary for the complete healing process [44]. During angiogenesis, several growth factors are expressed and regulated. However, it is known that VEGF is the main factor in this process, capable of promoting endothelial cell migration, proliferation, increased vascular permeability, and regulating neovascularization and tissue repair [44]. Thus, increased VEGF synthesis by fibroblasts exposed to EGF, regardless of the donor's age, indicates that this therapy can assist in angiogenesis and the tissue repair process. In this study, when E fibroblasts were irradiated, a lower concentration of this growth factor was detected. However, gene expression evaluation revealed that the $\mathrm{Y}$ and $\mathrm{E}$ cells subjected to LLLT demonstrated increased expression of VEGF. This result allows us to suggest that LLLT could have promoted earlier expression of this factor.

Analysis of the scientific data obtained in this in vitro study indicates that both tested therapies are capable of promoting biostimulatory effects in gingival fibroblasts obtained from young and elderly individuals and perhaps characterize interesting future therapeutic approaches to accelerate the wound healing process in oral mucosa. The proposed therapies assisted in the improvement of cellular functions of gingival fibroblasts obtained from young and elderly individuals during the repair process. According to the methodology used in this laboratorial study and based on the data obtained, it was possible to conclude that greater viability, collagen synthesis, migration, as well as expression and synthesis of growth factor occur in cultured fibroblasts exposed to EGF or submitted to a LLLT, independently of the age group assessed.

Acknowledgments The authors thank the São Paulo State Research Support Foundation (FAPESP) (grants 2012/25070-9 and 2013/058790 ) and the National Council for Scientific and Technological Development (CNPq) (grants 303599/2014-6 PQ and 443153/2014-0) for financial support. 


\section{Compliance with ethical standards}

Ethical approval All procedures performed in studies involving human participants were in accordance with the ethical standards of the Research Ethics Committee of the Araraquara School of Dentistry/ UNESP, after approval (CAEE no. 13514813.6.0000.5416).

Conflict of interest The authors have no conflicts of interest to declare.

Informed consent Informed consent was obtained from all individual participants included in the study.

Funding This study was funded by São Paulo State Research Support Foundation (FAPESP) (grants 2012/25070-9 and 2013/05879-0) and the National Council for Scientific and Technological Development (CNPq) (grants 303599/2014-6 PQ and 443153/2014-0).

\section{References}

1. Magalhães JP (2004) From cells to ageing: a review of models and mechanisms of cellular senescence and their impact on human ageing. Exp Cell Res 300:1-10

2. Gosain A, DiPietro LA (2004) Aging and wound healing. World J Surg 28:321-326

3. Schulze C, Wetzel F, Kueper T, Malsen A, Muhr G, Jaspers S, Blatt T, Wittern KP, Wenck H, Käs JA (2010) Stiffening of human skin fibroblasts with age. Biophysical J 99:2434-2442

4. Cristofalo VJ, Lorenzini A, Allen RG, Torres C, Tresini M (2004) Replicative senescence: a critical review. Mech Ageing Dev 125: 827-848

5. Hwang ES, Gyesoon Y, Kang HT (2009) A comparative analysis of the cell biology of senescence and aging. Cell Mol Life Sci 66: $2503-2524$

6. Reinke JM, Sorg H (2012) Wound repair and regeneration. Eur Surg Res 49:35-43

7. Cochran DL, Wozney JM (1999) Biological mediators for periodontal regeneration. Periodontol 19:40-58

8. Stephens P, Davies KJ, Al-Khateeb T, Shepherd JP, Thomas DW (1996) A comparison of the ability of intra-oral and extra-oral fibroblasts to stimulate extracellular matrix reorganization in a model of wound contraction. J Dent Res 75:1358-1364

9. Enoch S, Peake MA, Wall I, Davies L, Farrier J, Giles P, Kipling D, Price P, Moseley R, Thomas D, Stephens P (2010) 'Young' oral fibroblasts are geno/phenotypically distinct. J Dent Res 89:14071413

10. Häkkinen L, Uitto VJ, Larjava H (2000) Cell biology of gingival wound healing. Periodontol 24:127-152

11. Ohshima M, Sato M, Ishikawa M, Maeno M, Otsuka K (2002) Physiologic levels of epidermal growth factor in saliva stimulate cell migration of and oral epithelial cell line, HO-1-N-1. Eur J Oral Sci 100:130-136

12. Carpenter G, Cohen S (1990) Epidermal growth factor. J Biol Chem 265:7709-7712

13. Fujisawa K, Miyamoto Y, Nagayama M (2003) Basic fibroblast growth factor and epidermal growth factor reverse impaired ulcer healing of the rabbit oral mucosa. J Oral Pathol Med 32:358-366

14. Barrientos S, Stojadinovic O, Golinko MS, Brem H, Tomic-Canic M (2008) Growth factors and cytokines in wound healing. Wound Rep Reg 16:585-601
15. Ryu S, Moon SY, Yang Y, Moon SR, Hong JP, Choi J, Lee SW (2009) Recombinant human epidermal growth factor accelerates the proliferation of irradiated human fibroblasts and keratinocytes in vitro and in vivo. J Radiat Res 50:545-552

16. Kong Q, Majeska RJ, Vazquez M (2011) Migration of connective tissue-derived cells is mediated by ultra-low concentration gradient fields of EGF. Exp Cell Res 317:1491-1502

17. Choi JK, Jang JH, Jang WH, Kim J, Bae IH, Bae J, Park YH, Kim BJ, Lim KM, Park JW (2012) The effect of epidermal growth factor (EGF) conjugated with low-molecular-weight protamine (LMWP) on wound healing of the skin. Biomaterials 33:8579-8590

18. Hardwicke J, Schmaljohann D, Boyce D, Thomas D (2008) Epidermal growth factor therapy and wound healing - past, present and future perspectives. Surgeon 6:172-177

19. Marques MM, Pereira NA, Fujihara NA, Nogueira FN, Eduardo CP (2004) Effect of low-power laser irradiation on protein synthesis and ultrastructure of human gingival fibroblasts. Lasers Surg Med 34:260-265

20. Hawkins DH, Abrahamse H (2006) The role of lasers fluence in cell viability, proliferation, and membrane integrity of wounded human skin fibroblasts following helium-neon lasers irraditation. Lasers Surg Med 38:74-83

21. Damante CA, De Micheli G, Miyagi SPH, Feist IS, Marques MM (2009) Effect of laser phototherapy on the release of fibroblast growth factors by human gingival fibroblasts. Lasers Med Sci 24: 885-891

22. Basso FG, Pansani TN, Turrioni APS, Bagnato VS, Hebling J, de Souza Costa CA (2012) In vitro wound healing improvement by low-level laser therapy application in cultured gingival fibroblasts. Int J Dent 2012:719452. doi:10.1155/2012/719452

23. Basso FG, Oliveira CF, Kurachi C, Hebling J, Costa CAS (2013) Biostimulatory effect of low-level laser therapy on keratinocytes in vitro. Lasers Med Sci 28:367-374

24. Basso FG, Pansani TN, Soares DG, Scheffel DL, Bagnato VS, de Souza Costa CA, Hebling J (2015) Biomodulation of inflammatory cytokines related to oral mucositis by low-level laser therapy. Photochem Photobiol 91(4):952-956

25. Pansani TN, Basso FG, Turirioni AP, Kurachi C, Hebling J, de Souza Costa CA (2014) Effects of low-level laser therapy on the proliferation and apoptosis of gingival fibroblasts treated with zoledronic acid. Int J Oral Maxillofac Surg 43:1030-1034

26. Karu TI (2008) Michocondrial signaling in mammalian cells activated by red and near-IR radiation. Photochem Photobiol 84:10911099

27. Basso FG, Oliveira CF, Fontana F, Bagnato VS, Hebling J, de Souza Costa CA (2011) In vitro effect of low level laser therapy on typical oral microbial biofilms. Braz Dent J 5:502-510

28. Khadra M, Lyngstadaas SP, Haanæs HR, Mustafa K (2005) Effect of laser therapy on attachment, proliferation and differentiation of human osteoblast-like cells cultured on titanium implant material. Biomaterial 26:3503-3509

29. Fujihara NA, Hiraki KRN, Marques MM (2006) Irradiation at $780 \mathrm{~nm}$ increases proliferation rate of osteoblasts independently of dexamethasone presence. Lasers Surg Med 38:332-336

30. Hoang AM, Oates TW, Cochran DL (2000) In vitro wound healing responses to enamel matrix derivative. J Periodontol 71:1270-1277

31. Tullberg-Reinert H, Jundt G (1999) In situ measurement of collagen synthesis by human bone cells with a sirius red-based colorimetric microassay: effects of transforming growth factor beta 2 and ascorbic acid 2-phosphate. Histochem Cell Biol 112:271-276

32. Eleftheriou CS, Trakas NB, Tzartos SJ (1991) Cellular ageing related proteins secreted by human fibroblasts. Mutat Res 256:127138

33. Dunlevy JR, Couchman JR (1993) Controlled induction of focal adhesion disassembly and migration in primary fibroblasts. J Cell Sci 105:489-500 
34. Beurden HEV, Snoek PAM, Von den Hoff JW, Torensma R, Maltha JC, Kuijpers-Jagtman AM (2006) In vitro migration and adhesion of fibroblasts from different phases of palatal wound healing. Wound Rep Reg 14:66-71

35. Lallier TE, Miner QW Jr, Sonnier J, Spencer A (2007) A simple cell motility assay demonstrates differential motility of human periodontal ligament fibroblasts, gingival fibroblasts, and pre-osteoblasts. Cell Tissue Res 328:339-354

36. Smith KC (2005) Laser (and LED) therapy is phototherapy. Photomed Laser Surg 23:78-80

37. Desmet KD, Paz DA, Corry JJ, Eells JT, Wong-Riley MT, Henry MM (2006) Clinical and experimental applications of NIR-LED photobiomodulation. Photomed Laser Surg 24:121-128

38. Kreisler M, Christoffers AB, Willershausen B, d'Hoedt B (2003) Effect of low-level GaAlAs laser irradiation on the proliferation rate of human periodontal ligament fibroblasts: an in vitro study. J Clin Periodontol 30:353-358
39. Posten W, Wrone DA, Dover JS, Arndt KA, Silapunt S, Alam M (2005) Low-level laser therapy for wound healing: mechanism and efficacy. Dermatol Surg 31:334-339

40. AlGhamdi KM, Kumar A, Moussa NA (2012) Low-level laser therapy: a useful technique for enhancing the proliferation of various cultured cells. Lasers Med Sci 27:237-249

41. Pratsinis H, Kletsas D, Stathakos D (1997) Autocrine growth regulation in fetal and adult human fibroblasts. Biochem Biophys Res Commun 237:348-353

42. Yeo E, Jang I, Lim H, Ha K, Park SC (2002) Agonist-specific differential changes of cellular signal transduction pathways in senescent human diploid fibroblast. Exp Gerontol 37:871-883

43. Shiraha H, Gupta K, Drabik K, Wells A (2000) Aging fibroblasts present reduced epidermal growth factor (EGF) responsiveness due to preferential loss of EGF receptors. J Biol Chem 275:19343-19351

44. Bates DO, Jones ROP (2003) The roles of vascular endothelial growth factor in wound healing. Int J Low Extrem Wounds 2:107-120 